\title{
THE EFFECTS OF KEFIR ON THE INFLAMATORY STATUS AND THYROID FUNCTION (EXPERIMENTAL STUDY ON WISTAR RATS AFTER EXPOSED TO CHLORPYRIFOS)
}

\author{
RASIPIN RASIPIN ${ }^{1 *}$, EDI DHARMANA ${ }^{1}$, SUHARYO HADISAPUTRO ${ }^{1}$, SUHARTONO SUHARTONO ${ }^{1,2}$ \\ ${ }^{1}$ Doctoral Program of Medical and Health Science, Faculty of Medicine, Diponegoro University, Semarang, Jawa Tengah, Indonesia. ${ }^{2}$ Faculty \\ of Public Health, Diponegoro University, Semarang, Jawa Tengah, Indonesia. Email: rasipinbrebes@gmail.com
}

Received: 28 May 2016, Revised and Accepted: 20 June 2016

\section{ABSTRACT}

Objective: Goiter is an enlarged thyroid gland remained a health problem in the agricultural areas. Chlorpyrifos (CPF) is a pesticide widely used by farmers. Previous studies proved that CPF exposure caused thyroid dysfunction. The objective of this study was to evaluate the effects of kefir on the inflammatory status and thyroid function in male Wistar rats after exposed to CPF using biochemical and histopathological assays.

Methods: Male rats were divided into 4 groups, i.e., CPF 5+kefir ( $5 \mathrm{mg} / \mathrm{kg}+3.6 \mathrm{ml} / 200 \mathrm{~g}$, respectively), CPF 5 (5 mg/kg), corn oil (CO $1 \mathrm{ml} / 200 \mathrm{~g}$ ), and negative control (NC: Without CPF, CO, and kefir).

Results: Kefir supplementation dose $3.6 \mathrm{ml} / 200 \mathrm{~g}$ once a day for 28 days in the rats after exposed to CPF dose $5 \mathrm{mg} / \mathrm{kg}$ once a day for 14 days, in CPF 5+kefir as compared to CPF 5: Significantly $(\mathrm{p}<0.05)$ decreased serum tumor necrosis factor- $\alpha$ (TNF- $\alpha)$ level; significantly $(p<0.01)$ maintained serum levels of transforming growth factor- $\beta$ (TGF- $\beta$ ) and thyroid stimulating hormone (TSH) not to decrease; not significant ( $p>0.05$ ) decreased the level of interleukin-1 $\beta$ (IL-1 $\beta$ ), cluster of differentiation-26 (CD26) expression and level of $\mathrm{T}_{4}$ serum; not significant ( $\left.p>0.05\right)$ maintained the level of anti-thyroid peroxidase not to decrease; and not significant $(p>0.05)$ increased the apoptosis index. This study suggests that $C P F$ exposure causes the inflammatory process which leads to thyroid dysfunction.

Conclusion: Kefir supplementation significantly decreased the level of TNF- $\alpha$ and maintained the levels of TGF- $\beta$ and TSH not to decrease, possible to reduce the inflammatory and thyroid dysfunction processes caused by exposure to CPF in experimental animals.

Keywords: Kefir, Chlorpyrifos, Inflammation, Thyroid function.

(C) 2016 The Authors. Published by Innovare Academic Sciences Pvt Ltd. This is an open access article under the CC BY license (http://creativecommons. org/licenses/by/4. 0/) DOI: http://dx.doi.org/10.22159/ajpcr.2016.v9i5.13122

\section{INTRODUCTION}

High prevalence of goiter, especially on primary school (PS) children with normal urinary iodine excretion (UIE) remains a health problem in agricultural areas. In working area of Kluwut Primary Health Care, Bulakamba Subdistrict, total goiter rate (TGR) in PS children had increased from 2012 to 2014 (32.17\%, 48.97\%, and 50.46\%, respectively). Data from Brebes District Health Office in 2010 showed UIE in PS children in Kluwut was 286-293 $\mu \mathrm{g} / \mathrm{l}$ [1]. According to WHO, UEI $\geq 100 \mu \mathrm{g} / \mathrm{l}$ was categorized as adequate [2]. The TGR in Kluwut was very high compared to a national survey in 2003, which showed TGR in PS children was $11.2 \%$ and median UIE $229 \mu \mathrm{g} / \mathrm{l}$ [3]. The WHO determines an area with TGR $\geq 30.0 \%$ is categorized as high endemic of goiter [2]. Bulakamba is a center of onion production in brebes. Chlorpyrifos (CPF) an organophosphate insecticide is a widely used pesticide in the area, especially by onion farmers.

Exposure to CPF has been reported differently by several researchers that CPF exposure has caused thyroid follicular cells proliferation, necrosis, or apoptosis [4-6]. Previous studies proved that CPF exposure could cause an increasing or a decreasing thyroid stimulating hormone (TSH) and thyroxine hormone $\left(\mathrm{T}_{4}\right)$ levels [6-10]. We assumed that CPF affected thyroid dysfunction, but it was not clear whether the CPF affected hypothyroidism or hyperthyroidism and have not reported a possible the inflammatory process in the pathogenesis of thyroid dysfunction caused by CPF exposure.

The cells apoptosis result of CPF exposure may affect to other cells. Although apoptosis appears to play a role in the pathogenesis of both Hashimoto's thyroiditis (HT) and Graves' disease (GD), the mechanisms that mediate, these processes appear different. The induction of apoptosis in HT results in the destruction of thyrocytes, while apoptosis in the GD leads to damage of thyroid-infiltrating lymphocytes. The differences in the apoptotic mechanisms produce two very different forms of thyroid autoimmune responses, eventually developing into HT and GD, respectively [11]. Thyroid follicular cells apoptosis can be sensitized by pro-inflammatory cytokines interferon- $\gamma$ (IFN- $\gamma$ ) and interleukin-1 $\beta$ (IL-1 $\beta$ ) or tumor necrosis factor- $\alpha$ (TNF- $\alpha$ ) and IL-1 $\beta$ through the mediation of Fas ligand or TNF-related apoptosis-inducing ligand [12-14]. Previous studies proved that the levels of TNF- $\alpha$ and IL$1 \beta$ increased also correlated with GD [15-18].

Previous studies reported that exposure to CPF increased the levels of TNF- $\alpha$ and IL- $1 \beta$, increased the production of IFN- $\gamma$ after induced by lipopolysaccharide and the expression of a cluster of differentiation-26 (CD26) as well as decreased the levels of IL-10 and transforming growth factor- $\beta$ (TGF- $\beta$ ) [19-25]. Based on this description, it can be concluded that CPF exposure induces pro-inflammatory cytokines TNF- $\alpha$, IFN- $\gamma$, and IL-1 $\beta$. Apoptosis in thyroid follicular cells or thyroid-infiltrating lymphocytes on the pathogenesis of thyroid dysfunction are possible through sensitization of these pro-inflammatory cytokines caused by CPF exposure.

Kefir has a role as anti-inflammatory and anti-apoptosis. Lactic acid bacteria in kefir modulate the immune system to produce antiinflammatory cytokines IL-10 and TGF- $\beta$ [26-28]. IL-10 acts as an immunostimulatory through increases the life expectancy of the cells by increasing the production of anti-apoptosis B-cell lymphoma-2 (Bcl-2) [29]. The effects of anti-inflammatory IL-10 are thought to be caused by a reduced production of the pro-inflammatory cytokines IL12 , IFN- $\gamma$ and TNF- $\alpha$ while TGF- $\beta$ regulates the adaptive immune system directly inhibit T-cell proliferation by reducing the production of IL-2 and repressing level of IL- $1 \beta$ induced proteinase-activated receptor-2 expression. IL-10 and TGF- $\beta$ also play a role in therapy in autoimmune disease models [27,29-31]. 
Kefir has a role as a regulator as anti-apoptosis and pro-apoptosis The role of anti-apoptosis kefir is to reduce the levels of pro-apoptotic protein Bcl-2-associated-x (bax), Bcl-2-associated agonist of cell death (bad), sitokom c, caspase-3, and decrease the level of the proinflammatory cytokine TNF- $\alpha$ [32]. Lactobacillus rhamnosus GG on kefir activates the anti-apoptotic akt/protein kinase B. This model probiotic also inhibits activation of the pro-apoptotic p38/mitogen-activated protein kinase (MAPK) by TNF- $\alpha$, IL- $1 \alpha$, and INF- $\gamma$ [33]. The role of pro-apoptosis kefir is to upregulate the ratio of protein bax/Bcl-2 and increase the expression of p53 independent p21 expression. The apoptosis increases with increasing kefir concentration. Western blot analysis demonstrates that kefir induces the overexpression of bax while repressing Bcl-2 [34,35]. Previous studies have not reported the role of kefir as anti-inflammation in the case of thyroid dysfunction caused by CPF exposure. This study aimed to investigate the efficacy of anti-inflammatory properties of kefir on Wistar rats after exposed to CPF causing thyroid dysfunction.

\section{METHODS}

\section{Animals}

This study was carried out by using male Wistar rats (250-400 g). Rats were obtained from the Integrated Research and Development Institute of Unit IV (LPPT) Gadjah Mada University in Yogyakarta. The animals were maintained under standard laboratory conditions (temperature $\left.27-32^{\circ} \mathrm{C}\right)$ with dark and light cycle $(12 / 12 \mathrm{hrs})$ and allowed free access to standard pellet diet (The National Agency of Drug and Food Control, Indonesia) and water ad libitum. The rats were acclimatized to laboratory condition for 1 week before the commencement of experiment. All procedures described conducted in accordance with Guideline for Care and Use of Animals Laboratory of LPPT. This study was approved by the Research Ethics Committee for Health Research No. 62/EC/FK-RSDK/2015, Faculty of Medicine, Diponegoro University and Dr. Kariadi General Hospital, Semarang, Indonesia.

\section{CPF, corn oil (CO) and kefir}

CPF (Dursban ${ }^{\circledR} 200$ EC) was obtained from Store for Trading Pesticides and Agriculture Appliances in Brebes, Indonesia. Dursban ${ }^{\circledR} 200$ EC examined using gas chromatography method was proven that this insecticide containing CPF $218.5 \mathrm{~g} / \mathrm{l}$. Before Dursban was given to experimental animals orally by gavage, it was dissolved in $\mathrm{CO}$ for a final concentration of $0.5 \mathrm{mg} / \mathrm{ml}$. CO was obtained from local supermarkets in Brebes, Indonesia in the form of refined $\mathrm{CO}$ with plastic packaging. Kefir was made from the $24 \mathrm{hrs}$ fermented cow milk by kefir grains commercial inoculum that obtained from the House of Kefir Ungaran, Semarang, Indonesia.

\section{Experimental study}

Randomized control group pre- and post-test design performed on 36 Wistar rats were divided into 4 groups, i.e., (1) CPF 5+kefir and, (2) CPF 5 , rats were coadministered CPF $5 \mathrm{mg} / \mathrm{kg}\left(1 /{ }_{50} \mathrm{LD}_{50}\right)$, (3) CO, rats, were coadministration CO $1 \mathrm{ml} / 200 \mathrm{~g}$. CPF (dissolved in CO) and CO were given orally by gavage once a day for 14 days. Kefir was given from the $15^{\text {th }}$ to $42^{\text {nd }}$ days ( 28 days) dose $3.6 \mathrm{ml} / 200$ g orally by gavage once a day. Pre- and post-test data were measured on $14^{\text {th }}$ and $42^{\text {nd }}$ days, including levels of TNF- $\alpha$, IL-1 $\beta$, and TGF- $\beta$; expression of CD26; levels of TSH, $\mathrm{T}_{4}$ and antithyroid peroxidase antibody (anti-TPO). One rat of each group was sacrificed for histopathology examination for hematoxylin and eosin ( $\mathrm{H}$ and $\mathrm{E}$ ) staining and immunohistochemical with caspase-3 staining (thyroid follicle cells apoptosis index). Four negative control (NC), the data in this study to determine the value that was considered normal were also taken as above in rats without treatment of CPF, CO and kefir as an NC. The data were measured only at the time of the posttest.

\section{Evaluation of the inflammatory status and thyroid function}

Cytokines (TNF- $\alpha$, IL-1 $\beta$, and TGF- $\beta$ ), hormones (TSH and $\mathrm{T}_{4}$ ) and antiTPO concentrations were assayed using double-antibody sandwich enzyme-linked immunosorbent one-step process assay kit (Qayee-Bio,
Shanghai China). CD26 kit using rat CD26 (OX61): Sc-53039 Santa Cruz Biotechnology Inc. USA and CD26 expression was analyzed using flow cytometer.

\section{Histopathological study}

Skin of the neck was incised, and trachea was removed. Thyroid gland on the posterior aspect of trachea was removed. They were washed in saline, dried by a filter paper and then they were fixed in $10 \%$ neutral buffered formal and processed for paraffin blocks. $5 \mu \mathrm{m}$ paraffin sections were cut and stained with $\mathrm{H}$ and $\mathrm{E}$ stain for routine histopathological study.

\section{Immunohistochemical stains for thyroid sections}

The rabbit polyclonal anti-active/cleaved caspase-3 antibody (Novus Biologicals, Littleton, Colorado, USA) was used. To ensure antibody specificity, NC samples were processed under the same conditions but without using the primary antibody. Brown color in the cytoplasm was considered a positive reaction. The percent area of positive cells was measured using image analysis in five randomly selected, separate, ×400 magnified fields from each slide.

\section{Statistical analysis}

The data were presented as the mean \pm standard deviation. The differences pre- and post-test were analyzed using Paired t-test or Wilcoxon. The differences among the three groups with NC were analyzed using independent t-test or Mann-Whitney. The statistical significance of differences between the groups was assessed with a one-way ANOVA or Kruskal-Wallis test, followed by Duncan post-hoc test analysis.

\section{RESULTS}

\section{The effect of kefir on the inflammatory status} The effect of kefir on serum TNF- $\alpha$ level

The effect of kefir on serum TNF- $\alpha$ level of rats after to exposed CPF is presented in Fig. 1A. Pre-test data showed TNF- $\alpha$ level in CPF $5+$ kefir and CPF 5 higher than NC rated significant $(\mathrm{p}<0.05)$, but in CO lower than NC not significant $(p>0.05)$. TNF- $\alpha$ level after 28 days (posttest) significantly decreased $(p<0.05)$ only in CPF $5+$ kefir and CO, but on CPF 5 decreased not significant ( $p>0.05$ ). Test of delta $(\Delta)$ TNF- $\alpha$ level (Table 1) with ANOVA in three groups rated significant $(\mathrm{p}<0.05)$. post-hoc analysis with Duncan test showed that decreasing level of TNF- $\alpha$ in CPF $5+$ kefir more than CPF 5. In CPF 5 decreased fewest.

\section{The effect of kefir on serum $I L-1 \beta$ level}

Pre-test data (Fig. 1B) showed IL-1 $\beta$ level in CPF 5+kefir, CPF 5, and CO higher than $\mathrm{NC}$, but not significant ( $\mathrm{p}>0.05)$. Post-tests data showed IL$1 \beta$ level in CPF $5+$ kefir decreased not significant ( $p>0.05)$, but on CPF 5 and CO increased not significant ( $p>0.05)$. Test of $\Delta$ IL-1 $\beta$ level (Table 1) with ANOVA in three groups rated not significant $(p>0.05)$. Post-hoc analysis with Duncan test showed that decreasing level of IL- $1 \beta$ most differs occurred in the group CPF $5+$ kefir.

\section{The effect of kefir on serum TGF- $\beta$ level}

Pre-test data (Fig. 1C) showed TGF- $\beta$ level in CPF $5+$ kefir, CPF 5, and CO higher than NC, but not significant ( $p>0.05$ ). Post-test data showed TGF- $\beta$ level in CPF 5 decreased significant $(\mathrm{p}<0.05)$, in CPF $5+$ kefir, deceased not significant $(p>0.05)$ whereas in CO group TGF- $\beta$ level increased not significant ( $p>0.05$ ). Test of $\Delta$ TGF- $\beta$ level (Table 1 ) with ANOVA in three groups rated significant $(\mathrm{p}<0.01)$. Post-hoc analysis with Duncan test showed that decreasing TGF- $\beta$ level in the most different in CPF 5, whereas in CPF 5+kefir decreased fewest.

\section{The effect of kefir on serum CD26 expression}

Pre-test data (Fig. 1D) showed CD26 expression in CPF 5+kefir significantly $(\mathrm{p}<0.001)$, CPF $5(\mathrm{p}<0.001)$ and CO $(\mathrm{p}<0.01)$ higher than NC. Post-test data showed that expression of CD26 in CPF 5+kefir significantly $(\mathrm{p}<0.001)$, CPF $5(\mathrm{p}<0.01)$ and CO $(\mathrm{p}<0.01)$ decreased. $\Delta$ 


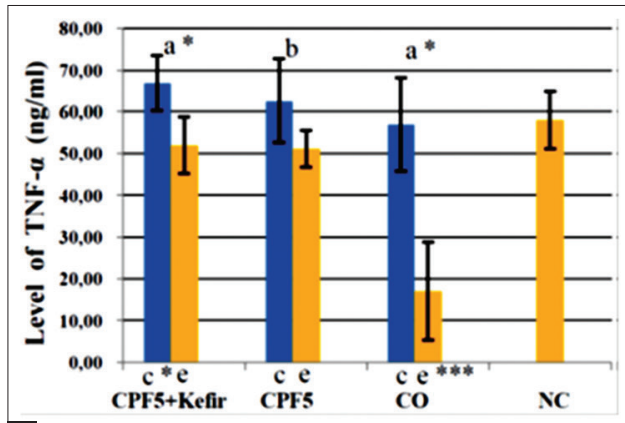

A

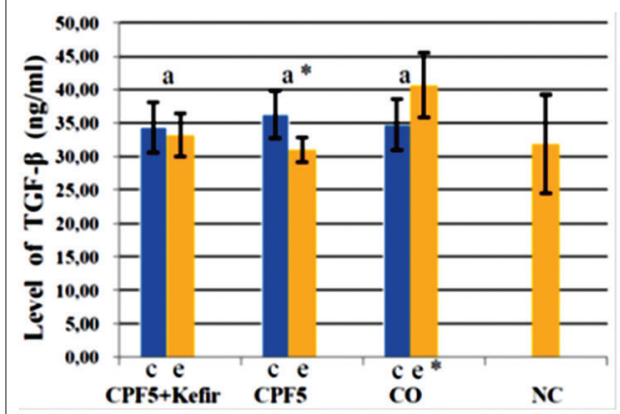

Pretest Posttest

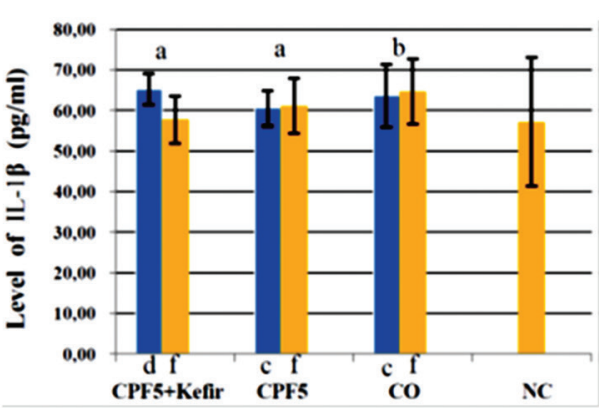

B

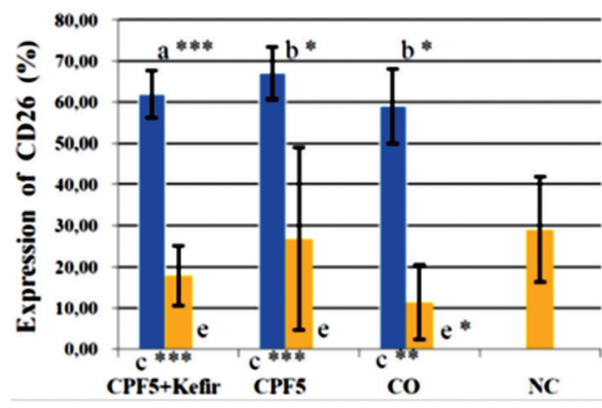

D

Fig. 1: Serum tumor necrosis factor- $\alpha$ level (A), interleukin-1 $\beta$ level (B), transforming growth factor- $\beta$ level (C) and cluster of differentiation-26 expression (D) of the rats in each group. Data were expressed as mean \pm standard deviation for seven rats in each group. Pre- and post-test data in the same group were compared using: Paired t-test (a), or Wilcoxon test (b), Data of each groups were compared with negative control by using: Independent t-test (c: pre-test; e: post-test) or Mann-Whitney test (d: pre-test; f: post-test). The significant different was expressed by: ${ }^{*} \mathbf{p}<0.05 ;{ }^{* *} \mathbf{p}<0.01 ;{ }^{* * *} \mathbf{p}<0.001$

Table 1: Summary data of changes $(\Delta)$ in the value of various variables among groups of experimental animals

\begin{tabular}{|c|c|c|c|c|}
\hline \multirow[t]{2}{*}{ Variables } & \multicolumn{3}{|c|}{$\Delta$ Experimental animal groups } & \multirow[t]{2}{*}{$\mathbf{p}$} \\
\hline & CPF5+Kefir & CPF5 & $\mathrm{CO}$ & \\
\hline TNF- $\alpha(\mathrm{ng} / \mathrm{ml})$ & $-14.93 \pm 10.16$ & $-11.46 \pm 12.46$ & $-39.93 \pm 18.15$ & $0.011 \mathrm{~g}^{*}$ \\
\hline $\mathrm{IL}-1 \beta(\mathrm{pg} / \mathrm{ml})$ & $-7.44 \pm 7.73$ & $0.65 \pm 5.14$ & $1.08 \pm 10.00$ & $0.375 \mathrm{~g}$ \\
\hline TGF- $\beta$ (ng/ml) & $-1.17 \pm 4.37$ & $-5.28 \pm 3.96$ & $5.89 \pm 8.03$ & $0.008 \mathrm{~g}^{* *}$ \\
\hline CD26 (\%) & $-44.07 \pm 8.71$ & $-42.32 \pm 2.22$ & $-47.43 \pm 13.77$ & $0.550 \mathrm{~g}$ \\
\hline $\mathrm{TSH}(\mathrm{ng} / \mathrm{ml})$ & $-3.26 \pm 12.92$ & $-35.37 \pm 18.10$ & $-39.02 \pm 25.54$ & $0.009 \mathrm{~h}^{* *}$ \\
\hline $\mathrm{T}_{4}(\mathrm{ng} / \mathrm{ml})$ & $-5.44 \pm 8.83$ & $-3.93 \pm 15.09$ & $-1.33 \pm 12.56$ & $0.891 \mathrm{~g}$ \\
\hline Anti-TPO $(\mathrm{ng} / \mathrm{ml})$ & $-1.91 \pm 12.33$ & $-3.03 \pm 6.13$ & $-3.34 \pm 8.61$ & $0.912 \mathrm{~g}$ \\
\hline Apoptosis index (\%) & $5.00 \pm 1.41$ & $0.50 \pm 2.12$ & $-4.50 \pm 0.71$ & $0.102 \mathrm{~h}$ \\
\hline
\end{tabular}

Data were expressed as mean of $\triangle \pm$ SD for seven rats in each group. g: One-way ANOVA test; $\mathrm{h}$ : Kruskal-Wallis test, ${ }^{*} \mathrm{p}<0.05,{ }^{* *} \mathrm{p}<0.01$, significantly different to each groups. CPF: Chlorpyrifos, CO: Corn oil, TNF- $\alpha$ : Tumor necrosis factor- $\alpha$, IL-1 $\beta$ : Interleukin-1 $\beta$, TGF- $\beta$ : Tumor growth factor- $\beta$, TSH: Thyroid stimulating hormone, TPO: Thyroid peroxidase, $\Delta$ : Delta

CD26 expression in CPF 5+kefir decreased more than CPF 5. Test of $\Delta$ CD26 expression (Table 1) with ANOVA in three groups rated not significant $(p>0.05)$. Post-hoc analysis with Duncan test showed that decreasing CD26 expression most differs occurred in $\mathrm{CO}$, but in $\mathrm{CPF}$ 5+kefir decreased more than CP5. In CPF 5 decreased fewest.

\section{The effect of kefir on the thyroid function}

The effect of kefir on serum TSH level

The effect of kefir on serum TSH level of rats after exposed to CPF is presented in Fig. 2A. Pre-test data showed TSH level in CPF+kefir, CPF 5 and $\mathrm{CO}$ lower than $\mathrm{NC}$, but not significant $(\mathrm{p}>0.05)$. Post-test data showed TSH level in CPF 5 significantly $(\mathrm{p}<0.01)$ and CO $(\mathrm{p}<0.05)$ decreased, but in CPF $5+$ +kefir decreased not significant ( $p>0.05)$. Test of $\Delta$ TSH level (Table 1) with Kruskal-Wallis in three groups rated significant $(\mathrm{p}<0.01)$. Post-hoc analysis with Duncan test showed that decreasing TSH level most differs occurred in CO, but in CPF 5 decreased more than CP 5+kefir. In CPF 5+kefir decreased fewest.
The effect of kefir on serum $T_{4}$ level

The effect of kefir on serum $\mathrm{T}_{4}$ level of rats after exposed to CPF is presented in Fig. 2B. Pre-test data showed $\mathrm{T}_{4}$ level in CPF $5+$ kefir, CPF 5 and $\mathrm{CO}$ not significantly higher than $\mathrm{NC}(\mathrm{p}>0.05)$. Post-test data showed $\mathrm{T}_{4}$ level in CPF $5+$ kefir, CPF 5 and CO decreased not significant ( $p>0.05)$. Posttest $\mathrm{T}_{4}$ level in CPF $5+$ kefir is almost the same as $\mathrm{NC}$, while in the other two groups are still higher than NC ( $p>0.05)$. Test of $\Delta \mathrm{T}_{4}$ level (Table 1) with ANOVA in three groups was not significant $(p>0.05) . \Delta T_{4}$ level most decreased in CPF 5+kefir then CPF 5 and CO. In CO decreased fewest.

\section{The effect of kefir on serum anti-TPO level}

The effect of kefir on serum anti-TPO level of rats after exposed to CPF is presented in Fig. 2C. Pre-test data showed the anti-TPO level in CPF $5+$ kefir and CPF 5 higher than NC, but in CO lower than NC ( $>0.05)$. Post-test data showed the anti-TPO level in CPF $5+$ kefir, CPF 5 and CO decreased not significant $(p<0.05)$. Test of $\Delta$ (Table 1) the anti-TPO level with ANOVA in three groups rated not significant ( $p>0.05)$. Post-hoc 


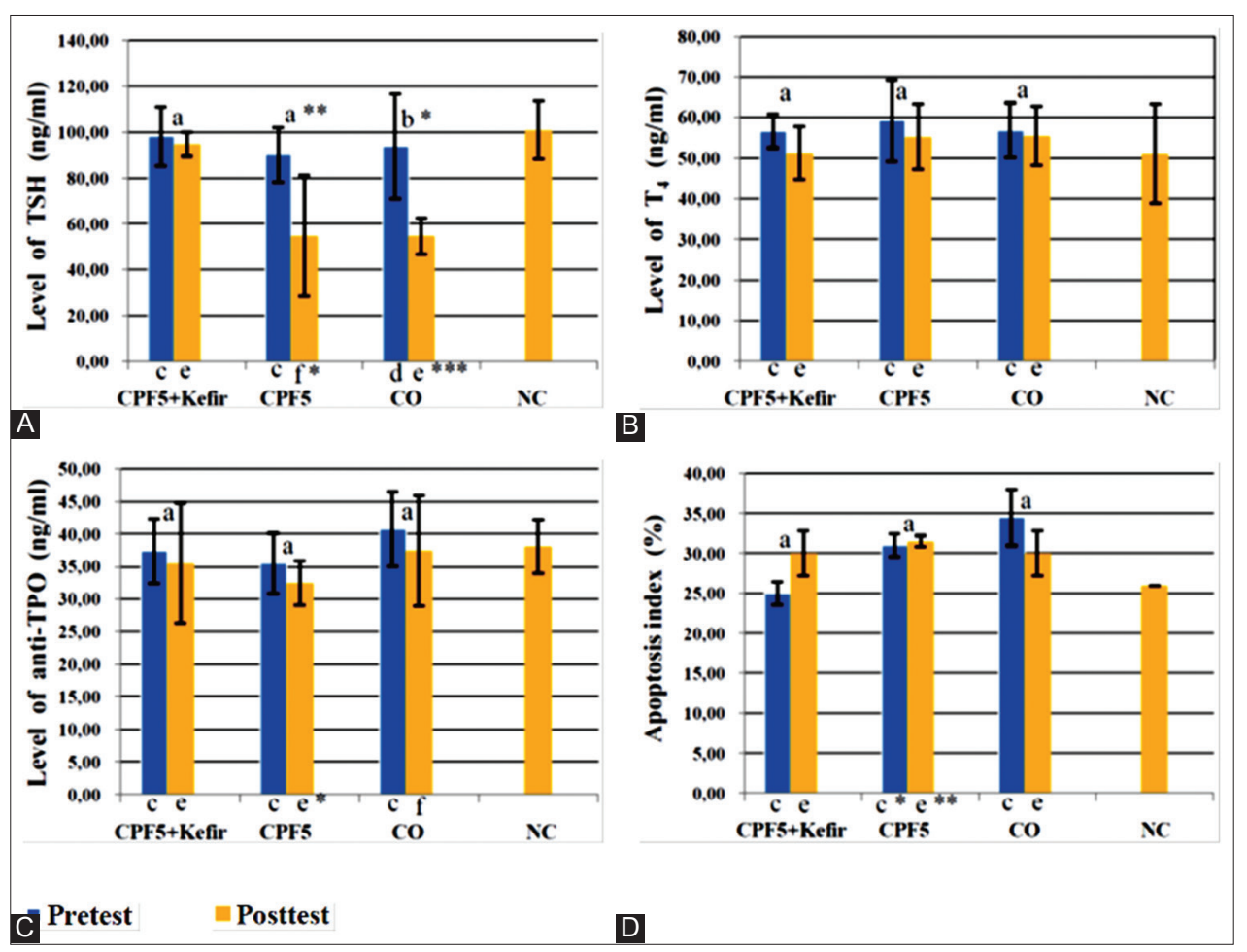

Fig. 2: Serum thyroid stimulating hormone level (A), T4 level (B), anti-thyroid peroxidase level (C) and apoptosis index (D) of the rats in each group. Data were expressed as mean \pm standard deviation for seven rats in each group. Pre-test and post-test data in the same group were compared using: Paired t-test (a), or Wilcoxon test (b), data of each group were compared with NC by using: Independent $t$-test

(c: pre-test; e: post-test) or Mann-Whitney test (d: pre-test; f: post-test). The significant different was expressed by: *p<0.05; ${ }^{* *} \mathbf{p}<0.01 ;{ }^{* * *} \mathbf{p}<0.001$

analysis with Duncan test showed decreasing the anti-TPO level in the most different in CPF 5 and CO, whereas in CPF 5-kefir decreased fewest. In CPF 5+kefir decreased fewest.

\section{The effect of kefir on serum apoptosis index}

The effect of kefir on the apoptosis index of rats after exposed to CPF is presented in Fig. 2D. Post-test data showed apoptosis index in CPF 5 -kefir, and CPF 5 increased not significant $(\mathrm{p}<0.05)$, whereas in CO decreased not significant $(\mathrm{p}>0.05)$. The apoptosis index in CPF 5-kefir increased more than CPF 5. Test of $\Delta$ (Table 1) the apoptosis index in three groups with Kruskal-Wallis in this study rated not significant ( $>>0.05$ ). Test of $\Delta$ (Table 1 ) the apoptosis index with Kruskal-Wallis in three groups were not significant ( $p>0.05)$. $\Delta$ the apoptosis index most increased in CPF $5+$ kefir, but in $\mathrm{CO}$ decreased.

\section{DISCUSSION}

The result of this study showed similar with the previous study that exposure to CPF increased the level of TNF- $\alpha[19,20]$. The previous study revealed significant increase of TNF- $\alpha$ secretion among CPF-exposed workers. Enhancement of TNF- $\alpha$ release was explained by the fact that insecticides modulate immune response via different mechanisms: Thllike immune response was enhanced with the release of cytokines (IL-2 and TNF- $\alpha$ ) affecting B-cell maturation and immunoglobulin production The IL-2 and TNF- $\alpha$ increase may result from a mechanism to compensate for the decrease in TNF- $\gamma$ after Insecticide exposure [19]. Protein kinases like the Akt family or extracellular signal-regulated kinase (ERK), which are essential for cell survival and proliferation, were inhibited by CPF [22] Kefir supplementation dose $3.6 \mathrm{ml} / 200 \mathrm{~g}$ significantly reduced level of TNF- $\alpha$ in Wistar rats after exposed to CPF $5 \mathrm{mg} / \mathrm{kg}$. Kefir modulated the immune system to produce anti-inflammatory cytokines IL-10 [26,28]. IL-10 promoted the development of a Type 2 cytokine pattern by inhibiting the IFN- $\gamma$ production of T lymphocytes directly inhibited the proliferation of CD4+ T-cells and production of cytokines such as IL-2, IFN- $\gamma$, IL-4, IL-5, and TNF- $\alpha$ [29]. Kefir also contains Saccharomyces cerevisiae [36]. In vitro studies, $S$. cerevisiae var. boulardii role in blocking the activation of nuclear factor kappa B (NF-kB) and MAPK decreases the expression of inflammation-associated cytokines, such as IL-8, TNF- $\alpha$, and IFN- $\gamma$. Antiinflammatory effect of $S$. cerevisiae var. boulardii exerts anti-inflammatory effects after stimulation with Clostridium difficile-toxin A due to decrease in secretion of IL-8 in human colonocytes and activation of ERK 1/2 in both human colonocytes and murine ileal loops also decreased level of IL-8 in human colon and activated signal ERK 1/2 in human colon and ileum murine $[36,37]$. IL-10, expressed by macrophages and dendritic cells, is dependent on the activation of ERK 1/2 [22].

This study similar with previous study that exposure to CPF increased the level of IL-1 $\beta[22,23]$. The previous study revealed that several stress stimuli (chemical stress, osmotic shock, heat shock) induced 5-lipooxygenase product formation in freshly isolated polymorphonuclear leukocytes, in parallel with activation of p38 MAPK [38]. Leukotriene $B_{4}$, a major product of 5 -lipoxygenase, has been shown to augment the IL-1 $\beta$ release [39]. Exposure to CPF increases the level of IL- $1 \beta$ in the rats serum, possible through an increasing the enzyme 5-lipooksigenase who played a major role in producing leukotriene $B_{4}$. Kefir supplementation dose $3.6 \mathrm{ml} / 200 \mathrm{~g}$ reduced level of IL- $1 \beta$ after exposed to CPF $5 \mathrm{mg} / \mathrm{kg}$, but not significant ( $p>0.05)$. Kefir modulated the immune system to produce anti-inflammatory cytokine TGF- $\beta[26,28]$. TGF- $\beta$ acts as an inhibitor of the actions of IL- 2 and IL-1 $\beta[29,30,40]$. Kefir also contains Lactobacillus helventicus [36]. The oral administration of L. helventicus HY7801 in Candida albicansinfected mice induced a reduction of NF- $\kappa B$ activation in the vaginal tissue, decreased the expression of IL- $1 \beta$, TNF- $\alpha$, IL- 6 , cyclooxygenase-2, and inducible nitric oxide synthase, and increased the expression of IL10. The role of $L$. helventicus $\mathrm{Bc}-10$ in reducing the production of IL-1 $\beta$ by inhibiting the activity of leukotriene $\mathrm{B}_{4}$ has been proved increasing the level of IL-1 $\beta[39,41]$. 


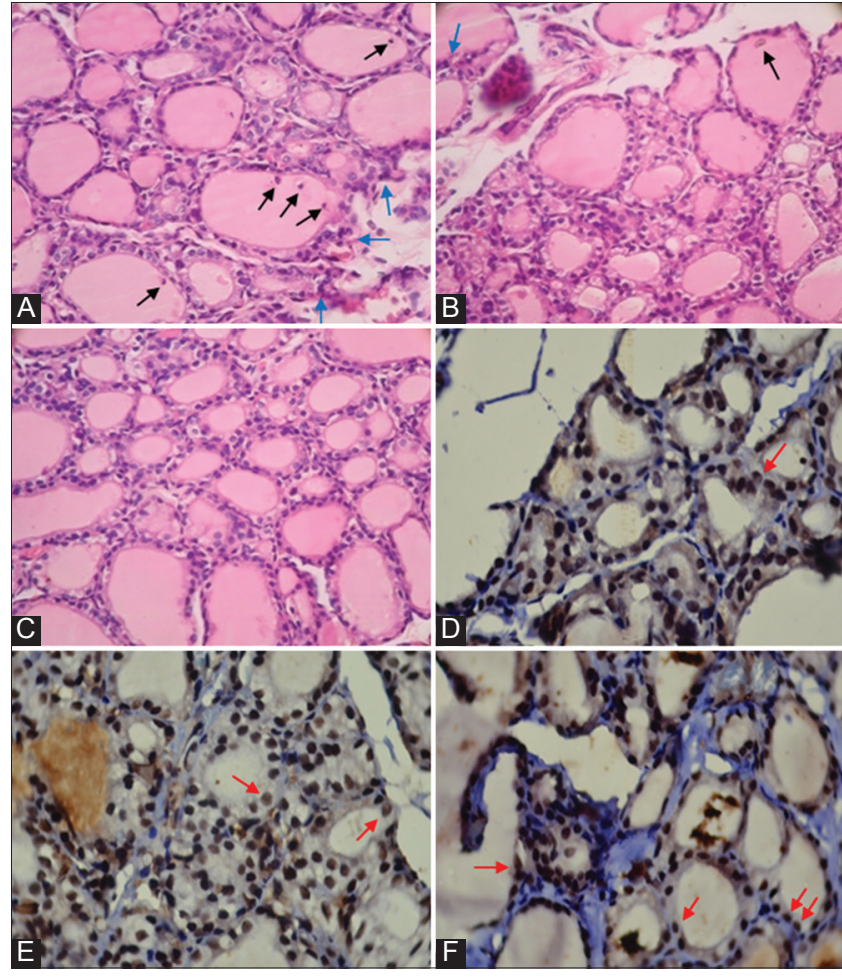

Fig. 3: A-C represent photomicrographs of thyroid section of experimental rats $\mathrm{H}$ and $\mathrm{E}(\times 400)$ and $D-F$ represent immunohistochemical with cappase- 3 staining $(\times 1000)$. In which $A$ and $D$ represent thyroid gland after exposed to chlorpyrifos $5 \mathrm{mg} / \mathrm{kg}$ once daily for 14 days (pre-test); B and $\mathrm{E}$ after 28 days exposure to chlorpyrifos stopped (post-test) without Kefir supplementation; $C$ and $F$ with kefir. Blue arrows in $A$ showed lymphocytes infiltration, black arrow in A and B showed debris or necrotic cells exfoliated into the colloid. $C$ showed normal structure. Red arrows in D, E, and F showed positive caspase-3 staining (follicular cell apoptosis)

This study is consistent with previous study that exposure to CPF reduced the level of TGF- $\beta$ [25]. Kefir supplementation $3.6 \mathrm{ml} / 200 \mathrm{~g}$ for 28 days significantly maintained the TGF- $\beta$ level not to decrease (relative increasing) after exposed to CPF $5 \mathrm{mg} / \mathrm{kg}$. TGF- $\beta$ is produced by Th 3 cells mainly in the gastrointestinal mucosa; therefore, Th 3 cells are very important in maintaining the tolerance of antigens orally [42] The ability of kefir as probiotics maintained the level of TGF- $\beta$ not to decrease after exposure to CPF because kefir has been shown to improve homeostasis gastrointestinal tract. The interaction between probiotic strains and enterocytes is important for the controlled production of cytokines and chemokines secreted by epithelial cells. Indeed, it has been shown that some probiotic organisms can modulate the in vitro expression of pro and anti-inflammatory molecules in a strain-dependent manner. For instance, Lactobacillus sakei induces the expression of IL-1 $\beta$, IL-8, and TNF- $\alpha$, whereas Lactobacillus johnsonii stimulates the production of TGF- $\beta$ in caco- 2 cells. This process appears to require cross-talk between the epithelial cells and the underlying leukocytes $[27,43]$.

The result of this study is consistent with previous study that exposure to CPF in this study increased the CD26 expression [24]. Exposure to CPF increases level of IL-2 [19]. The previous study reported that both IL-2 and IL-12 up-regulated the expression of adenosine deaminase and CD26 [44]. High CD26 cell surface expression is correlated with the production of Th1-type cytokines such as IFN- $\gamma$ [45], it is correlated with the production of TNF- $\alpha$ and IL- $\beta$. Kefir supplementation $3.6 \mathrm{ml} / 200 \mathrm{~g}$ decreased expression of CD26 after exposure to CPF dose $5 \mathrm{mg} / \mathrm{kg}$ but not significant. The role of kefir is to inhibit the activity of CD26 through $\beta$-lactoglobuline which is produced by Lactococcus lactis and through the ability to decrease the level of IL-2 [46,47]. In this study, the ability of kefir in decreasing expression of CD26 is correlated with the ability to decrease the levels of TNF- $\alpha$ and IL- $\beta$, which increased after exposure to $\mathrm{CPF}$ and maintain TGF- $\beta$ level not to decrease.

The previous study proved that exposure to CPF decreased level of TSH $[9,10]$. In this study, post-test data showed that the TSH level decreased in conjunction with increasing the TNF- $\alpha$ and IL- $1 \beta$ levels possible were caused by the inflammatory processes in central nervous system. It is suspect that exposure to CPF may cause inflammation on the pituitary or hypothalamus gland. Previous study showed that the monocrotophos (organophosphate) pesticide disturbed the thyroid hormones (THs) homeostasis and interfered with the transport and conversion of THs, synthesis and secretion of pituitary TSH, and regulation of hypothalamic thyrotropin-releasing hormone (TRH) in female goldfish [48]. Obstacles the activity of acetylcholinesterase (AChE) enzymes caused by organophosphate exposure will increase the acetylcholine level. After cholinergic activation, leading to somatostatin release TRH secretion will be inhibited. There is evidence that acetylcholine is involved in regulating pituitary functions. Several lines of evidence support a role for cholinergic regulation of TSH secretion through by somatostatin. Dopamine stimulates somatostatin release from the median eminence and increases its portal blood concentration and this increase suppresses the serum TSH level [49]. Organophosphate exposure, even if there are no obstacles the activity of AChE enzymes, still can induce inflammation through increased production of cytokines such as TNF- $\alpha$, IL-1 $1 \beta$, and IL- 6 in the cortex, hippocampus, and thalamus of rats [50]. The toxic effect of CPF on the central nervous system which reduced the TSH level could be through the inflammatory processes. Kefir supplementation significantly maintained (relative increasing) the TSH level not to decrease after exposure to CPF, possible caused the effects of kefir as an anti-inflammation to reduces the activity of cytokines such as TNF- $\alpha$, IL- $1 \beta$ in the brain.

This study is similar with previous study that exposure to CPF tends to increase the $\mathrm{T}_{4}$ level [10]. Kefir supplementation dose $3.6 \mathrm{ml} / 200 \mathrm{~g}$ for 28 days in Wistar rats tends to decreased level of $\mathrm{T}_{4}$ after exposed to $\mathrm{CPF}$ $5 \mathrm{mg} / \mathrm{kg}$. Based on this study, exposure to CPF caused decreasing the level of TSH and tends to increase the level of $\mathrm{T}_{4}$, so thyroid dysfunction in this study was likely to cause hyperthyroidism. The previous study has proved that increasing the levels of TNF- $\alpha$ and IL- $1 \beta$ correlated with GD. In addition, IL-1 $\beta$ induces production of hyaluronan by primary thyroid epithelial cells and thyroid fibroblasts, a process that may contribute to the development of goiter in GD [15-18].

High level of IL- $1 \beta$ and low level of TGF- $\beta$ can be correlated with high levels of autoantibodies. In the development of GD, infiltration of the thyroid by activated immune cells results in local release of IL-1 $1 \beta$. It has been observed that IL- $1 \beta$ induces the production of IL-6, IL-8, intercellular adhesion molecule- 1 , and other inflammatory mediators. IL- $1 \beta$ also enhances $\mathrm{T}$ cell-dependent antibody production by augmenting CD40 ligand and OX40 expression on T-cells. IL-1 $\beta$ was shown to promote differentiation of T-helper 17 (Th17) cell, the proportion of which was reported to be higher in intractable GD than that of GD in remission [15]. In fact, patients with autoimmune diseases, such as systemic lupus erythematosus (SLE), have reduced TGF- $\beta$ production in their peripheral blood cell cultures. Hence, reduced TGF- $\beta$ production by immune cells might predispose to autoreactive T-cell activation and autoantibody production in autoimmune diseases [51]. CD26 is a multifunctional ectoenzyme involved in T-cell activation that has been implicated in autoimmune pathophysiology. CD26 may contribute to the orchestration of the immune response by Th17 cells in human inflammatory diseases. IL-17-producing CD4+ T-cells (Th17 cells) are important mediators of autoimmune disease [52].

In vitro study, CPF exposure in JEG-3 choriocarcinoma cell line modulated the mRNA levels of pro-inflammatory IL-6, IL-17 and the anti-inflammatory IL-13 cytokines [53]. IL-17 promotes the survival 
and expansion of B-cells and the differentiation of B-cells into antibodyproducing plasma cells. This may leads to autoimmunity. IL-17 also induces the production of other pro-inflammatory cytokines, such as TNF- $\alpha$ and IL-1 $\beta$ [54]. Antibodies against thyroid antigens are present in GD and HT diseases, but their specific epitopes are different, resulting in different functional antibodies. Autoimmune thyroid disease development occurs due to loss of immune tolerance to autoantigens and reactivity of the thyroid, which leads to infiltration of the gland by T-cells and B-cells, which in turn produce antibodies specific for clinical manifestations of hyperthyroidism and hypothyroidism, GD and HT, respectively. IL-17 is secreted by Th17 cells; IL-17 play an important role in chronic inflammatory diseases such as asthma and SLE. The percentage of Th17 lymphocytes in GD patients not treated with antithyroid drugs higher than GD remission patients [55].

In this study, the levels of TNF- $\alpha$, IL-1 $\beta$, and CD26 expression increased after exposed to CPF and the level of TGF- $\beta$ decreased in conjunction with increasing the inflammatory process on the thyroid gland (Fig. 3A), but not accompanied with increasing the level of anti-TPO (likely to fall). Kefir supplementation in this study tends to maintain anti-TPO level not to decrease after exposure to CPF, but not significant. Based on this study, exposure to CPF caused increasing the levels of TNF- $\alpha$, IL-1 $\beta$, and CD26 expression may be associated with increasing the other autoantibodies, especially TSH receptor antibody. This study is consistent with the previous study that the incidence of thyroid dysfunction after exposed to CPF significantly decreased the TSH level and was about to tend to increase the $\mathrm{T}_{4}$ level (hyperthyroidism) [10]. The newest case of organophosphorus (CPF) intoxication was reported that CPF intoxication present hyperthyroidism (decreasing the level of TSH and increasing the $\mathrm{T}_{4}$ level) [56].

The role of kefir decreasing the level of $\mathrm{T}_{4}$ is very likely related to the role of kefir as immunoregulatory by balancing the pro-apoptosis in thyroid follicular cells and anti-apoptosis in the process of thyroidinfiltrating lymphocytes, as well as the role of anti-inflammatory to reduced the levels of TNF- $\alpha$ and IL- $1 \beta$ and maintained the level of TGF- $\beta$. Kefir as imunoregulator can act as an anti-apoptosis and pro-apoptosis agent. In this study, the role of kefir enhances the apoptosis index (pro-apoptosis) on CPF5-kefir group (Fig. 3f) possible to decreased or normalized the level of $\mathrm{T}_{4}$ (almost equal with $\mathrm{NC}$ ) after exposure to $\mathrm{CPF}$. Lactic acid bacteria in kefir modulate the immune system to produce anti-inflammatory cytokines IL-10 and TGF- $\beta$ [26-28]. IL-10 and TGF- $\beta$, exhibit suppressive activities on macrophage functions and antagonize the effect of Th1-secreted cytokines. All of this may reflect the complexity of the feedback regulatory mechanisms that occur through the cytokine network in macrophages. IL-10 also exerted a suppressive effect on IL-17-induced TNF- $\alpha$ release, while the inhibitory effects of IL-4, IL-13, and TGF- $\beta 2$ on TNF- $\alpha$ secretion were partial [57] The data suggest a pivotal role for kefir in combating inflammatory and autoimmune responses are thought to be caused by CPF exposure.

\section{CONCLUSION}

The present study suggests that CPF exposure causes the inflammation through increasing the levels of TNF- $\alpha$, and decreasing the level of TGF- $\beta$. This inflammatory processes may interfere the pituitary-thyroid axis which causes thyroid dysfunction by decreasing the serum TSH level and tend to increasing the serum $\mathrm{T}_{4}$ level (hyperthyroidism). Based on this study, the role of kefir as an anti-inflammation is through the ability to decrease the serum level of TNF- $\alpha$, maintain the levels of TGF- $\beta$ and TSH not to decrease and tend to decrease the serum T level possible to cure thyroid dysfunction (hyperthyroidism) in the rats caused by exposure to CPF.

\section{ACKNOWLEDGMENT}

We would like to thanks to Prof. Dr. dr. J. B. Suparyatmo, Sp. PK (K) from Department of Clinical Pathology, Faculty of Medicine, Sebelas Maret University; Dr. Tjokorda G. D. Pemayun, Sp. PD (KEMD) from Department of Internal Medicine, Faculty of Medicine, Diponegoro University;
Dr. Judiono, MPS from Department of Nutrition, The Health Polytechnic of Bandung and Dr. Ari Suwondo, MPH from Faculty of Public Health, Diponegoro University to their contribution for this study.

\section{REFERENCES}

1. Office BDH. Brebes District Health Office the Republic of Indonesia Anual Report; 2014. (Unpublished).

2. Organization WH. WHO Assessment of iodine deficiency disorders and monitoring their elimination. A Guide for Programme Managers. $3^{\text {rd }}$ ed. Geneva: WHO Press; 2007. p. 3-3.

3. Helath M. Ministry of Health Republic of Indonesia Technical Assistance for Evaluation on Intensified Iodine Deficiency Control Project. Final Report; 2003. (Unpublished).

4. Kammon AM, Brar RS, Sodhi S, Banga HS, Singh J, Nagra NS Chlorpyrifos chronic toxicity in broilers and effect of Vitamin C. Open Vet J 2011;1(1):21-7.

5. De Angelis S, Tassinari R, Maranghi F, Eusepi A, Di Virgilio A, Chiarotti $\mathrm{F}$, et al. Developmental exposure to chlorpyrifos induces alterations in thyroid and thyroid hormone levels without other toxicity signs in CD-1 mice. Toxicol Sci 2009;108(2):311-9.

6. Shady AM, El-Deen FIN. Effect of chlorpyrifos on thyroid gland of adult male albino rats. Egypt J Histol 2010;33(3):441-50.

7. Ambali SF, Orieji C, Abubakar WO, Shittu M, Kawu MU. Ameliorative effect of Vitamin $\mathrm{C}$ on alterations in thyroid hormones concentrations induced by subchronic coadministration of chlorpyrifos and lead in wistar rats. J Thyroid Res 2011;2011:214924.

8. Muftau S, Aisha OO, Ambali SF, Oyedepo IT, Umaru KM, Yusuf PO, et al. ameliorative effect of hibiscus sabdariffa linn on subchronic chlorpyrifos-induced alterations in sex and thyroid hormones in male wistar rats. Am J of Pharmacol Toxicol 2014;9(1):96-106.

9. Lamfon HA. Effect of selenium on chlorpyrifos-induced thyroid toxicity in albino rats. Res in Endocrinol 2014;751500:1-11.

10. Fortenberry GZ, Hu H, Turyk M, Barr DB, Meeker JD. Association between urinary 3, 5, 6-trichloro-2-pyridinol, a metabolite of chlorpyrifos and chlorpyrifos-methyl, and serum T4 and TSH in NHANES 1999-2002. Sci Total Environ 2012;424:351-5.

11. Wang SH, Baker JR. The role of apoptosis in thyroid autoimmunity. Thyroid 2007;17(1):975-9.

12. Bretz JD, Arscott PL, Myc A, Baker JR Jr. Inflammatory cytokine regulation of Fas-mediated apoptosis in thyroid follicular cells. J Biol Chem 1999;274(36):25433-8.

13. Bretz JD, Mezosi E, Giordano TJ, Gauger PG, Thompson NW, Baker JR Jr. Inflammatory cytokine regulation of TRAIL-mediated apoptosis in thyroid epithelial cells. Cell Death Differ 2002;9(3):274-86.

14. Mezosi E, Wang SH, Utsugi S, Bajnok L, Bretz JD, Gauger PG, et al Induction and regulation of Fas-mediated apoptosis in human thyroid epithelial cells. Mol Endocrinol 2005;19(3):804-11.

15. Chen ML, Liao N, Zhao H, Huang J, Xie ZF. Association between the IL1B (-511), IL1B (3954), IL1RN (VNTR) polymorphisms and Graves' disease risk: A meta-analysis of 11 case-control studies. PLoS One 2014;9(1):e86077.

16. Gianoukakis AG, Khadavi N, Smith TJ. Cytokines, Graves' disease, and thyroid-associated ophthalmopathy. Thyroid 2008;18(1):953-8

17. Liu YH, Chen RH, Wu HH, Liao WL, Chen WC, Tsai Y, et al. Association of interleukin-1beta (IL1B) polymorphisms with Graves' ophthalmopathy in Taiwan Chinese patients. Invest Ophthalmol Vis Sci 2010;51(12):6238-46.

18. Simmonds MJ, Heward JM, Howson JM, Foxall H, Nithiyananthan R, Franklyn JA, et al. A systematic approach to the assessment of known TNF-alpha polymorphisms in Graves' disease. Genes Immun 2004;5(4):267-73.

19. Hamza RZ, Diab AE, Aziz SA, Hendawy AA. Immunotoxic effect of (organophosphorous insecticides) (chlorpyrifos, profenofos) and possible ameliorative role of propolis and ginseng. Biosci Biotechnol Res Asia 2013;10(2):645-51.

20. Hirani A, Lee WH, Kang S, Ehrich M, Lee YW. Chlorpyrifos induces pro-inflammatory environment in discrete regions of mouse brain. Abstract. FASEB J 2007;21:785.4.

21. Duramad P, Tager IB, Leikauf J, Eskenazi B, Holland NT. Expression of Th1/Th2 cytokines in human blood after in vitro treatment with chlorpyrifos, and its metabolites, in combination with endotoxin LPS and allergen Der p1. J Appl Toxicol 2006;26(5):458-65.

22. Schäfer M, Koppe F, Stenger B, Brochhausen C, Schmidt A, Steinritz D, et al. Influence of organophosphate poisoning on human dendritic cells. Chem Biol Interact 2013;206(3):472-8. 
23. Wang $\mathrm{X}$, Xing $\mathrm{H}, \mathrm{Li} \mathrm{X}, \mathrm{Xu} \mathrm{S}$, Wang $\mathrm{X}$. Effects of atrazine and chlorpyrifos on the mRNA levels of IL-1 and IFN-?2b in immune organs of common carp. Fish Shellfish Immunol 2011;31(1):126-33.

24. Thrasher JD, Heuser G, Broughton A. Immunological abnormalities in humans chronically exposed to chlorpyrifos. Arch Environ Health 2002;57(3):181-7.

25. Chen D, Zhang Z, Yao H, Cao Y, Xing H, Xu S. Pro- and antiinflammatory cytokine expression in immune organs of the common carp exposed to atrazine and chlorpyrifos. Pestic Biochem Physiol 2014;114:8-15

26. Chiba Y, Shida K, Nagata S, Wada M, Bian L, Wang C, et al. Wellcontrolled proinflammatory cytokine responses of Peyer's patch cells to probiotic Lactobacillus casei. Immunology 2010;130(3):352-62.

27. Delcenserie V, Martel D, Lamoureux M, Amiot J, Boutin Y, Roy D. Immunomodulatory effects of probiotics in the intestinal tract. Curr Issues Mol Biol 2008;10(1-2):37-54.

28. Lavasani S, Dzhambazov B, Nouri M, Fåk F, Buske S, Molin G, et al. A novel probiotic mixture exerts a therapeutic effect on experimental autoimmune encephalomyelitis mediated by IL-10 producing regulatory T cells. PLoS One 2010;5(2):e9009.

29. Su DL, Lu ZM, Shen MN, Li X, Sun LY. Roles of pro- and antiinflammatory cytokines in the pathogenesis of SLE. J Biomed Biotechnol 2012;2012:347141.

30. Tsai SH, Sheu MT, Liang YC, Cheng HT, Fang SS, Chen CH. TGFbeta inhibits IL-1beta-activated PAR-2 expression through multiple pathways in human primary synovial cells. J Biomed Sci 2009;16:97.

31. Choi EW. New Therapeutic Challenges in Autoimmune Diseases. Intech 2012;10. 5772(48207):253-80.

32. Wang HF, Tseng CY, Chang MH, Lin JA, Tsai FJ, Tsai CH, et al. Anti-inflammatory effects of probiotic Lactobacillus paracasi on ventricles of BALB/C mice treated with ovalbumin. Chin J Physiol 2012;55(1):37-46.

33. Yan F, Polk DB. Probiotic bacterium prevents cytokine-induced apoptosis in intestinal epithelial cells. J Biol Chem 2002;277(52):50959-65.

34. Rizk S, El-Hayek S. Kefir inhibits proliferation and induces apoptosis of epithelial colorectal adenocarcinoma cells. Abstract. FASEB J 2012;26:1.

35. Khoury N, El-Hayek S, Tarras O, El-Sabban M, El-Sibai M, Rizk S Kefir exhibits anti-proliferative and pro-apoptotic effects on colon adenocarcinoma cells with no significant effects on cell migration and invasion. Int J Oncol 2014;45(5):2117-27.

36. Farnworth ER. Kefir a complex probiotic. Food Sci Tech Bull Funct Foods 2005;2(1):1-17.

37. Moslehi-Jenabian S, Pedersen LL, Jespersen L. Beneficial effects of probiotic and food borne yeasts on human health. Nutrients 2010;2(4):449-73.

38. Werz O, Bürkert E, Samuelsson B, Rådmark O, Steinhilber D. Activation of 5-lipoxygenase by cell stress is calcium independent in human polymorphonuclear leukocytes. Blood 2002;99(3):1044-52.

39. Devaraj S, Jialal I. Alpha-tocopherol decreases interleukin-1 beta release from activated human monocytes by inhibition of 5-lipoxygenase. Arterioscler Thromb Vasc Biol 1999;19(4):1125-33.

40. Derman SG, Kol S, Shlomo IB, Resnick CE, Rohan RM, Adashi EY Transforming growth factor- $\beta 1$ is a potent inhibitor of interleukin- $1 \beta$ action in whole ovarian dispersates. J Endocrinol 1999;160:415-23.
41. Taverniti V, Guglielmetti S. Health-promoting properties of Lactobacillus helveticus. Front Microbiol 2012;3:392.

42. Lebeer S, Vanderleyden J, De Keersmaecker SC. Genes and molecules of lactobacilli supporting probiotic action. Microbiol Mol Biol Rev 2008;72(4):728-64

43. Haller D, Bode C, Hammes WP, Pfeifer AM, Schiffrin EJ, Blum S. Non-pathogenic bacteria elicit a differential cytokine response by intestinal epithelial cell/leucocyte co-cultures. Gut 2000;47(1):79-87.

44. Cordero OJ, Salgado FJ, Fernández-Alonso CM, Herrera C, Lluis C, Franco $\mathrm{R}$, et al. Cytokines regulate membrane adenosine deaminase on human activated lymphocytes. J Leukoc Biol 2001;70(6):920-30.

45. Ohnuma K, Takahashi N, Yamochi T, Hosono O, Dang NH, Morimoto C. Role of CD26/dipeptidyl peptidase IV in human T cell activation and function. Front Biosci 2008;13:2299-310.

46. Shigemori S, Oshiro K, Wang P, Yamamoto Y, Wang Y, Sato T, et al. Generation of dipeptidyl peptidase-IV-inhibiting peptides from B-lactoglobulin secreted by Lactococcus lactis. Biomed Res Int 2014;2014:393598

47. Carasi P, Racedo SM, Jacquot C, Romanin DE, Serradell MA, Urdaci MC. Impact of kefir derived Lactobacillus kefiri on the mucosal immune response and gut microbiota. J Immunol Res 2015;2015:361604.

48. Zhang X, Tian H, Wang W, Ru S. Monocrotophos pesticide decreases the plasma levels of total 3, 39, 5-triiodo-1-thyronine and alters the expression of genes associated with the thyroidal axis in female goldfish (Carassius auratus). Plos One 2014;9(9):1-9.

49. Satar S, Satar D, Kirim S, Leventerler H. Effects of acute organophosphate poisoning on thyroid hormones in rats. Am J Ther 2005;12(3):238-42.

50. Banks CN, Lein PJ. A review of experimental evidence linking neurotoxic organophosphorus compounds and inflammation. Neurotoxicology 2012;33(3):575-84.

51. Saxena V, Lienesch DW, Zhou M, Bommireddy R, Azhar M, Doetschman T, et al. Dual roles of immunoregulatory cytokine TGFbeta in the pathogenesis of autoimmunity-mediated organ damage. J Immunol 2008;180(3):1903-12.

52. Bengsch B, Seigel B, Flecken T, Wolanski J, Blum HE, Thimme R. Human Th17 cells express high levels of enzymatically active dipeptidylpeptidase IV (CD26). J Immunol 2012;188(11):5438-47.

53. Guiñazú N, Rena V, Genti-Raimondi S, Rivero V, Magnarelli G. Effects of the organophosphate insecticides phosmet and chlorpyrifos on trophoblast JEG-3 cell death, proliferation and inflammatory molecule production. Toxicol In Vitro 2012;26(3):406-13.

54. Zhu S, Qian Y. IL-17/IL-17 receptor system in autoimmune disease: Mechanisms and therapeutic potential. Clin Sci (Lond) 2012;122(11):487-511.

55. Mikos H, Mikos M, Obara-Moszynska M, Niedziela M. The role of the immune system and cytokines involved in the pathogenesis of autoimmune thyroid disease (AITD). Endokrynol Pol 2014;65(5):150-5.

56. Rao $\mathrm{BN}$ and Bhavana $\mathrm{R}$. Organophosphorous intoxication and hyperthyroidism. Case Report. Int J Res Med Sci 2015;3(10):2857-59.

57. Jovanovic DV, Di Battista JA, Martel-Pelletier J, Jolicoeur FC, He Y, Zhang M, et al. IL-17 stimulates the production and expression of proinflammatory cytokines, IL-beta and TNF-alpha, by human macrophages. J Immunol 1998;160(7):3513-21. 